\title{
Application of directional borehole grouting technology to structural complex floor reinforcement in deep underground coal mine
}

\section{Qiqing Wang • Wenping Li*}

School of Resources and Geosciences, China University of Mining and Technology, Xuzhou 221116, China.

Correspondence: wpligroup@163.com

\begin{abstract}
Water inrush from coal floor constitutes one of the main disasters in mine construction and mine production, which always brings high risks and losses to the coal mine safe production. As the mining depth of coal fields in North China gradually increased, especially in the complicated structural region, the threat posed by limestone karstic water of coal floor to the safe stoping of mines has become increasingly prominent. In this paper, the Taoyuan coalmine was taken as an example, for which, the directional borehole grouting technology was utilized to reinforce the coal seam floor prior to mining. Also, the factors affecting the grouting effect were analyzed. These were the geological structure, the crustal stress and the range of slurry diffusion. The layout principle of grouting drilling was put forward and the directional drilling structure was designed. The water level observations in the end hole indicated that the target stratum was accurate and reliable. The effect of grouting was validated through the audio frequency electric perspective method and the holedrilling in the track trough. The results demonstrated that the effect of grouting in third limestone and the rock stratum above the third limestone of coal seam floor was apparent. Simultaneously, no water inrush occurred following the actual mining of the working face, which further demonstrated that the grouting reinforcement effect was apparent. The research findings were of high significance for the prevention and control of floor water disaster and water conservation in deep complex structural areas.
\end{abstract}

Keywords Complicated structural region · Directional drilling · Grouting reinforcement · Coal floor $\cdot$ Karst aquifer 


\section{Introduction}

China is globally the producer and consumer of the highest amount of coal. A high number of disasters occur in the coalmines of China every year, in which water inrush is one of the major disasters. According to statistics, since 2000, more than 750 coal mine water inrush accidents occurred in China, while more than 3800 people died, resulting in direct economic losses, exceeding tens of billions of dollars (http://www.chinacoal-safety.gov.cn/mkaj/). As the mining depth of coal fields in North China gradually increases, the risk of water inrush in deep mines increases due to the effects of excavation disturbance and the inaccuracy of invisible water conducted structure exploration (For example, the detection rate of the collapse column can only reach to approximately30\%) (Sui et al. 2011; Li and Chen 2016; Sun et al. 2017). In particular, the lower-group coal mining in the North China coalfield, which is threatened by the karst water of the coal floor limestone, often causes catastrophic water inrush accidents as a result of the strong conducting-water structure zone (collapse column and concentrated fracture zone of structure) (Meng et al. 2009; Hu et al. 2014; Shi et al. 2017; Yang et al. 2017).

At present, the main methods for the prevention and control of limestone karst water in coal mines include drainage to lower water pressure and grouting reconstruction (Ge and Wang 2007; Wang et al. 2012; Cheng et al. 2013; Hao et al. 2014; Li and Du 2014; Tian et al. 2015; Sun et al. 2015). The drainage to lower water pressure method refers to the drainage of the aquifers in the floor prior to coal mining. This method is easily restricted by the water content of the aquifer, the condition of recharge, the thickness of floor aquiclude, the pressure and the drainage capacity of the mine, causing high amounts of groundwater waste. Conventional grouting reconstruction is mainly conducted through grouting in the underground tunnel or ground drilling, the plugging of fractures of the floor rock stratum and the tensile strength increase of the floor, to overcome the pressure of confined water and prevent water inrush from the working face. This method is difficult and inefficient due to underground grouting construction, while its effect is versatile. In addition, for ground drilling grouting, due to the high depth of Ordovician limestone, the cost is usually higher (Dong et al. 2014; Xu et al. 
2014).

To solve the problem of water inrush from coal floor as well as the shortage of conventional drilling grouting, in this paper, the Taoyuan coalmine was taken as an example. The directional borehole grouting technology was utilized to reinforce the coal seam floor prior to mining, to prevent and control the karst water disaster of the floor limestone. The layout principle and structure of the directional drilling were studied. The grouting effect was verified through geophysical prospecting and holedrilling in the track trough. The research findings were of high significance for the prevention and control of floor water disaster and water conservation in deep complex structural areas.

\section{Study Area}

The Huaibei coal mine district is located in the northern part of Anhui province. It lies at the intersection of the four provinces of Jiangsu, Shandong, Henan and Anhui, where as the geotectonic position is in the southeast margin of the North China plate. The east-west direction of the mining area is approximately $140 \mathrm{~km}$. The north-south direction is approximately $110 \mathrm{~km}$, while the entire area is approximately $15400 \mathrm{~km}^{2}$. The coal resources in the mining area are abundant and the coal quality is good. The entire region constitutes an important coal gathering area of the Carboniferous Permian system in China (Fig. 1).

The fault structures in the mining area have developed (More than 600 faults were found, of which, 170 exceeded 100m in drop height), while the mining geology and hydrogeological conditions are complex. The lower-groups of coal (6thand 10th) seams are mainly threatened by the thin limestone group (first limestone to fourth limestone) in the upper part of the Taiyuan formation and the deep Ordovician aquifer. The limestone of Taiyuan formation is mainly a medium - thin layer limestone, mainly with fractured karst water and the water-abundance is quite uneven. Most regions are characterized by high pressure and water-abundance as the depth increases. The distance between the coal seam and the Ordovician limestone is approximately 100 to $200 \mathrm{~m}$. In general (when the floor is relatively complete), the mine will not demonstrate karst water inrush from the Ordovician limestone during the mining of lower-groups. In the vertical invisible water conducting structure zone, with high-sized faults, collapse column and fracture zone, a hydraulic connection between Ordovician limestone water and thin limestone water exists. At present, three dimensional seismic exploration and other technologies are still difficult to accurately detect and determine the locations of water conducted structure zones. As the mining depth increases (beyond 
$520 \mathrm{~m}$ ), the water pressure increases, easily causing the high-sized Ordovician limestone water inrush into the mine, leading to mine disasters and major losses. In mines such as Yangzhuang, Taoyuan and Zhuzhuang, similar water inrush accidents have occurred.

Taking the Taoyuan coalmine as an example, the directional borehole grouting technology was utilized to reinforce the coal seam floor prior to mining, to prevent and control the karst water disaster of the floor limestone. The Taoyuan coalmine is located in the south of the Huaibei mining area (Fig. 1). The structural complexity of the study area was medium, presenting 12 faults at the drop height of beyond or equal to $10 \mathrm{~m}$, while the low-sized structures of the study were developed.

The third limestone in the study area was the thin limestone aquifer with the highest water abundance in the first limestone to the fourth limestone of the upper part of the Taiyuan formation, also constituting one of the main direct discharge aquifers for the 10th coal seam (Fig. 2). The grouting to reinforce third limestone could directly fill the thin layer limestone karst fracture. The third limestone had a high amount of fractures and strongly pourable. Consequently, it was easy to achieve the expected grouting reinforcement effect. Therefore, the third limestone was selected as the target layer for grouting reinforcement.

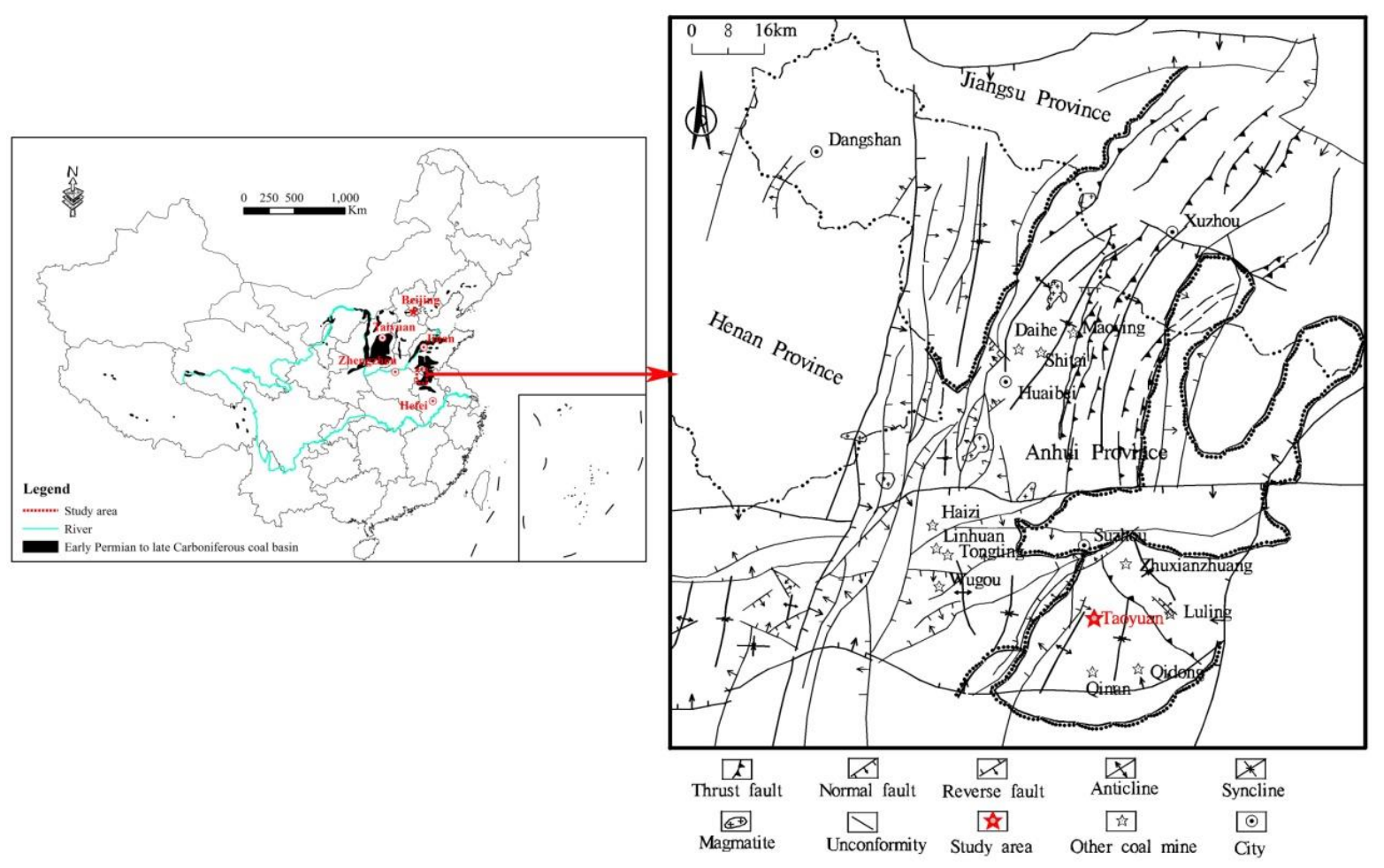

Fig. 1 Structure outline map of Huaibei Coalfield and location of study area 


\begin{tabular}{|c|c|c|c|c|c|}
\hline \multicolumn{3}{|c|}{ Strata } & \multirow{2}{*}{$\begin{array}{c}\text { Core } \\
\text { columns }\end{array}$} & \multirow{2}{*}{$\begin{array}{l}\text { Thickness (m) } \\
\frac{\text { Min Max }}{\text { Average }}\end{array}$} & \multirow{2}{*}{ Lithology } \\
\hline System & Series & Formation & & & \\
\hline \multirow{4}{*}{ Permain } & \multirow{4}{*}{$\begin{array}{l}\text { Lower } \\
\text { Permian }\end{array}$} & \multirow{4}{*}{$\begin{array}{l}\text { Shanxi } \\
\text { Formation }\end{array}$} & \multirow{4}{*}{ 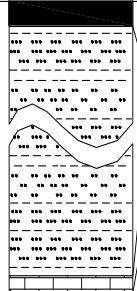 } & $\frac{2.2 \sim 4.0}{3.7}$ & 10th coal seam \\
\hline & & & & $\frac{56.0 \sim 59.8}{57.9}$ & $\begin{array}{l}\text { Combination of mud rock and } \\
\text { sandstone interbedded }\end{array}$ \\
\hline & & & & $\frac{2.1 \sim 3.0}{2.6}$ & First limestone \\
\hline & & & & $\frac{3.9 \sim 5.0}{4.5}$ & Sandy mudstone \\
\hline \multirow{6}{*}{ Carboniferous } & \multirow{6}{*}{$\begin{array}{c}\text { Upper } \\
\text { Carboniferous }\end{array}$} & \multirow{4}{*}{$\begin{array}{l}\text { Taiyuan } \\
\text { Formation }\end{array}$} & & $\frac{3.0 \sim 4.8}{3.9}$ & Second limestone \\
\hline & & & 等, & $\frac{5.8 \sim 6.5}{6.2}$ & $\begin{array}{l}\text { Combination of mud rock and } \\
\text { sandstone interbedded }\end{array}$ \\
\hline & & & 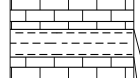 & $\frac{6.5 \sim 13.1}{9.8}$ & Third limestone \\
\hline & & & 1. & $\frac{3.2 \sim 5.0}{4.1}$ & Mudstone \\
\hline & & \multirow{2}{*}{$\begin{array}{c}\text { Benxi } \\
\text { Formation }\end{array}$} & & $\frac{3.5 \sim 8.7}{6.1}$ & Fourth limestone \\
\hline & & & 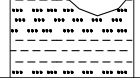 & $\frac{59.2 \sim 61.3}{60.3}$ & $\begin{array}{l}\text { Combination of mud rock and } \\
\text { sandstone interbedded }\end{array}$ \\
\hline Ordovician & $\begin{array}{c}\text { Middle } \\
\text { Ordovician }\end{array}$ & $\begin{array}{c}\text { Baitu } \\
\text { Formation }\end{array}$ & 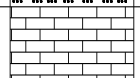 & $>500$ & Ordovician limestone \\
\hline
\end{tabular}

Fig. 2 Comprehensive typical strata column of coal seam floor for study area

\section{Directional borehole design}

\subsection{The layout orientation of grouting drilling}

3.1.1 Effect of geological structure on drilling orientation selection

The fractures, the faults, the water rich zone and the vertical water conducting structure zone of the third limestone in the coal seam floor were the object of the ground directional borehole grouting. Especially, the vertical water fault and the fold axis crack were the key points for the prevention and control of water inrush from the floor. Faults and their sides are usually accompanied by many structural fractures, forming tectonic fracture zones. Due to the strong interlayer shear in the formation of folds, the bedding joints of the limbs were developed. The lateral side of the turning end was subjected to tension and mainly distributed to tension joints. The core of the fold was strongly extruded, while the main distribution of the axial plane was cleavage.

The effects of fault and fold axis should be fully taken into account when the layout orientation of grouting drilling was designed. For the fissure-cavern limestone, between the transverse and longitudinal directions significant differences were displayed. If the horizontal section of a single drill is set along the vertical fissure strike, it will penetrate fewer cracks, 
which will be unfavorable for the grouting reconstruction to the water plugging. If the horizontal section of a single drill is set along the vertical fissure tendency, it will penetrate more cracks, which will be favorable for the slurry diffusion (Fig. 3). Therefore, the directional drilling locus should be highly intersected with the faults and other fractures.
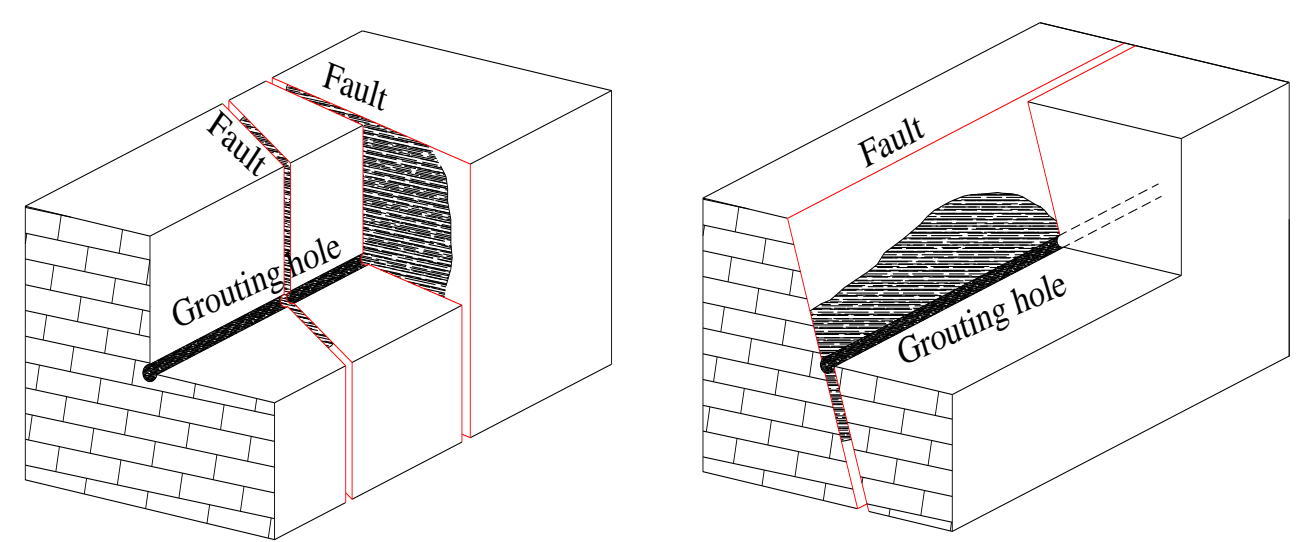

Fig.3 Sketch of grouting effect at different angles of drilling orientation and fault

\subsubsection{Effect of crustal stress on drilling orientation selection}

The orientation of directional drilling of horizontal section under the condition of complex stress distribution has a high effect on the direction of the induced grouting crack produced by high pressure splitting, which determines whether the fracture zone produced by the high-pressure grouting can be better connected to the natural fissure or not. Therefore, the stress distribution condition is an important basis for the orientation optimization of directional drilling of the horizontal section. For the initiation direction of splitting grouting, it is generally considered that the splitting plane is perpendicular to the minimum principal stress direction. This means that the initial crack is along the direction of the maximum principal stress (Lo and Kaniaru 1990; Zhou and Chen 2002). If the directional horizontal drilling is in accordance with the maximum horizontal principal stress direction, a longitudinal crack parallel to the drilling direction is produced. If the drilling is perpendicular to the direction of maximum horizontal principal stress, a transverse crack perpendicular to the drilling locus is produced (Fig. 4).

The longitudinal cracks are single and distribute along the maximum principal stress direction, while the splitting range is low. The transverse cracks are perpendicular to the 
horizontal drilling locus, while the splitting range is higher. The latter is more conducive to the diffusion of the slurry with high pressure splitting. Therefore, the vertical direction of maximum principal stress direction is the dominant position of the horizontal drilling locus.

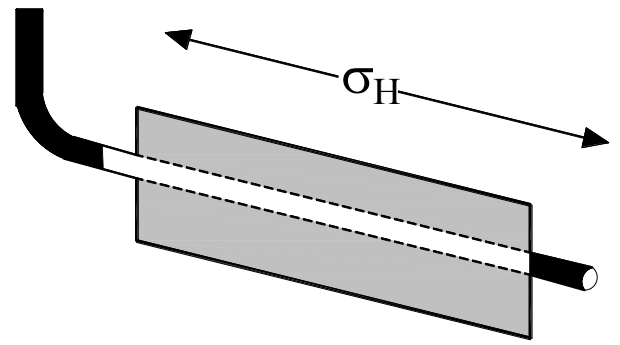

(a) longitudinal fissures parallel to horizontal drilling locus

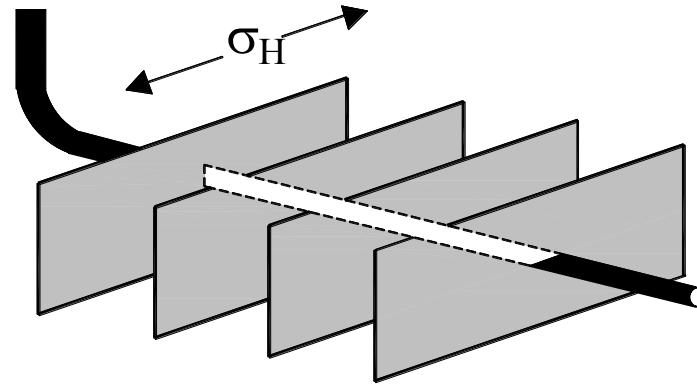

(b) transverse fissures perpendicular to horizontal drilling locus

Fig. 4 Sketch of relationship between horizontal drilling locus and splitting fissure orientation

\subsection{Grouting simulation of fractured rock mass}

In the process of slurry flow, the slurry pressure will cause the rock mass deformation, while the latter will also affect the slurry diffusion distance size and the final grouting effect. In this study, the geological and hydrogeological conditions of the study area were analyzed. The effective diffusion radius of the grouting slurry of third limestone was simulated with a two dimensional realistic failure process analysis code (RFPA2D-Flow) (Tang et al. 1998).

(1) Numerical calculation model and parameters

According to the geological survey data of the study area, the numerical model was designed (Fig. 5). The size of the model was $300 \mathrm{~m} \times 150 \mathrm{~m}$ and the elevation of the 10 th coal floor was approximately $-420 \mathrm{~m}$. The top and the floor were sandstone and mudstone, respectively. The third limestone water pressure was approximately $4 \mathrm{MPa}$ and the dip angle of the fault was approximately 60 degrees. The grouting drilling diameter was $152 \mathrm{~mm}$.

Based on the measured results of the crustal stress, the applied stress on the left boundary of the model was 9MPa. The upper boundary of the model as applied to the self-weight load of the overlying rock and soil (approximately10MPa). The displacements of the right boundary and the lower boundary were fixed, whereas the upper and lower boundaries of the model were impermeable boundaries. The first step was to make the model stable and the 
second step to simulate grouting. The grouting drilling was set to be conducted at the middle of the third limestone, while two steps were set to simulate the normal rock layer (first segment) and fault (second segment) grouting. The length of the grouting section was $60 \mathrm{~m}$ for each step. The diffusion rules of the slurries under the four grouting pressures of $4 \mathrm{MPa}, 8 \mathrm{MPa}$, $10 \mathrm{MPa}$ and $12 \mathrm{MPa}$ were simulated. The model parameters of numerical simulation are presented in Table 1.

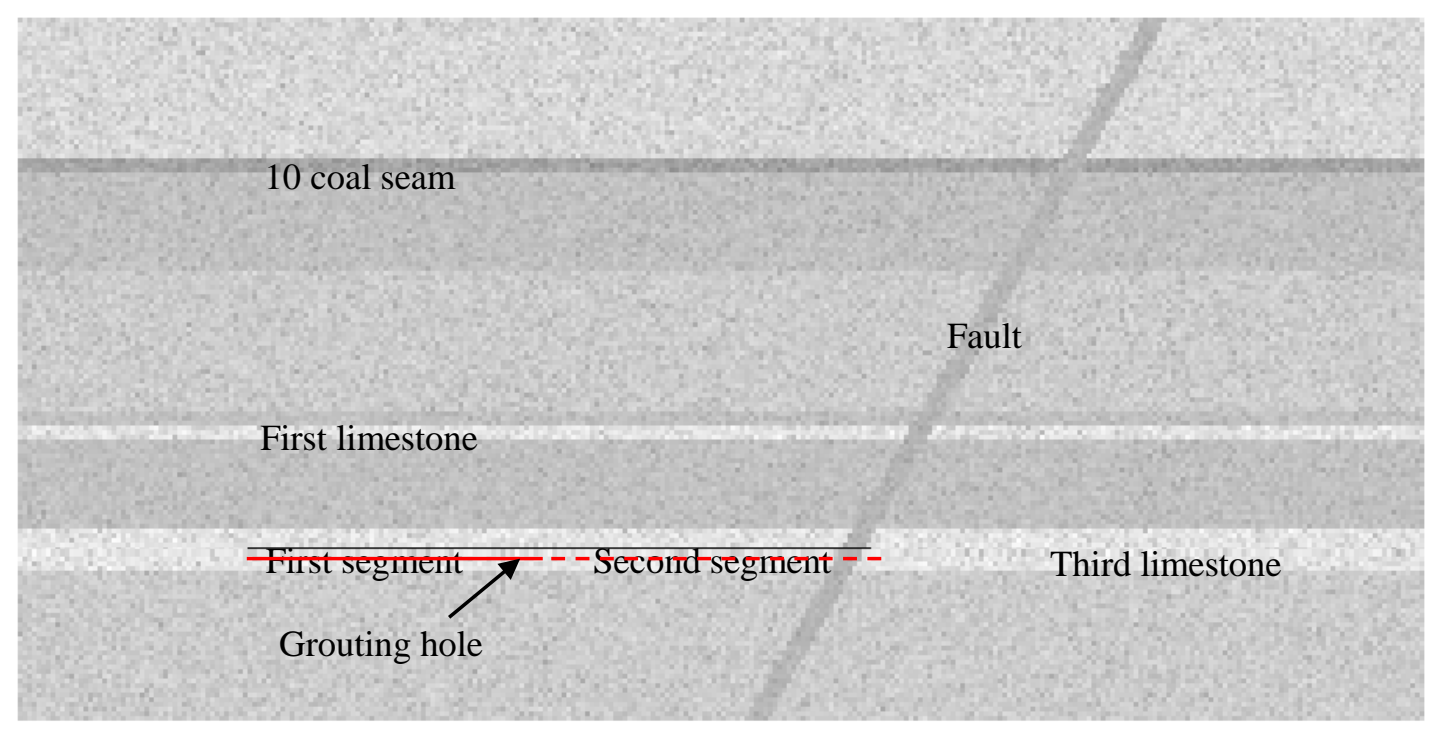

Fig. 5 Geological numerical model 
Table 1 Model parameters of numerical simulation

\begin{tabular}{|c|c|c|c|c|c|c|c|c|c|c|}
\hline \multirow[b]{2}{*}{ Model materials } & \multirow{2}{*}{$\begin{array}{c}\text { Thickness } \\
\text { (m) }\end{array}$} & \multirow{2}{*}{$\begin{array}{l}\text { Elastic modulus } \\
\qquad(\mathrm{GPa})\end{array}$} & \multirow{2}{*}{$\begin{array}{l}\text { Compressive } \\
\text { Strength } \\
(\mathrm{MPa})\end{array}$} & \multirow{2}{*}{$\begin{array}{c}\text { Friction angle } \\
\left({ }^{\circ}\right)\end{array}$} & \multirow[b]{2}{*}{ Poisson's ratio } & \multirow{2}{*}{$\begin{array}{l}\text { Density } \\
\left(\mathrm{kg} / \mathrm{m}^{3}\right)\end{array}$} & \multicolumn{2}{|c|}{ Permeability coefficient (m/d) } & \multirow[b]{2}{*}{ Porosity } & \multirow[b]{2}{*}{ Homogeneity } \\
\hline & & & & & & & Vertical direction & $\begin{array}{c}\text { Horizontal } \\
\text { direction }\end{array}$ & & \\
\hline Roof of coal seam & 30 & 8 & 33 & 30 & 0.25 & 2500 & 0.001 & 0.001 & 0.01 & 10 \\
\hline 10th coal seam & 3 & 3.5 & 10 & 30 & 0.30 & 1800 & 0.001 & 0.001 & 0.01 & 10 \\
\hline \multirow{2}{*}{ Floor of coal seam } & 22 & 6 & 33 & 36 & 0.25 & 2500 & 0.05 & 0.05 & 0.01 & 10 \\
\hline & 33 & 7 & 27 & 34 & 0.25 & 2500 & 0.05 & 0.05 & 0.01 & 10 \\
\hline First limestone & 2 & 11 & 70 & 35 & 0.30 & 2800 & 0.001 & 0.001 & 0.01 & 10 \\
\hline Floor of first limestone & 17 & 6 & 28 & 32 & 0.25 & 2500 & 0.05 & 0.05 & 0.01 & 10 \\
\hline Third limestone & 9 & 11 & 71 & 38 & 0.3 & 2800 & 2 & 2 & 0.1 & 5 \\
\hline Floor of third limestone & 34 & 7 & 40 & 32 & 0.25 & 2500 & 0.001 & 0.001 & 0.01 & 10 \\
\hline Fault & 4 & 4 & 10 & 30 & 0.25 & 2200 & 10 & 10 & 0.2 & 5 \\
\hline
\end{tabular}


(2) Simulation results and analysis

The results of numerical analysis are presented in Figure 6. It could be observed from Figure 6 that when the grouting pressure as $4 \mathrm{MPa}$, the slurry as mainly filled with natural fractures in the aquifer, while the grouting section was partially diffused to the third limestone roof. Also, the diffusion radius was approximately $13 \mathrm{~m}$. When the grouting drilling penetrated the fault, the slurry mainly diffused along the fault and the diffusion distance was approximately $60 \mathrm{~m}$.

1 When the grouting pressure increased to $8 \mathrm{MPa}$, the diffusion distance of the slurry gradually increased. Moreover, under the action of grouting pressure, the weak structural plane began to expand, especially the bedding, the fault zone and the contact zone. Also, the slurry diffusion radius was approximately $30 \mathrm{~m}$.

5 As the grouting pressure continued to increase (10MPa), the stress and tensile strengths of the weak part of the aquifer were exceeded. The splitting formed along the plane perpendicularly to the main stress plane, while the direction of the crack was the same as the direction of maximum principal stress. As the slurry was filled, the aquifer was strengthened further, while the radius of slurry diffusion was approximately $50 \mathrm{~m}$.

When the grouting pressure increased to $12 \mathrm{MPa}$, the original and split cracks were filled to a relatively high level. As the pressure increased, the filling became dense and the diffusion radius did not increase significantly, while the radius of diffusion slurry was approximately $55 \mathrm{~m}$. Adversely, the contact flow between the fault and the coal seam increased.
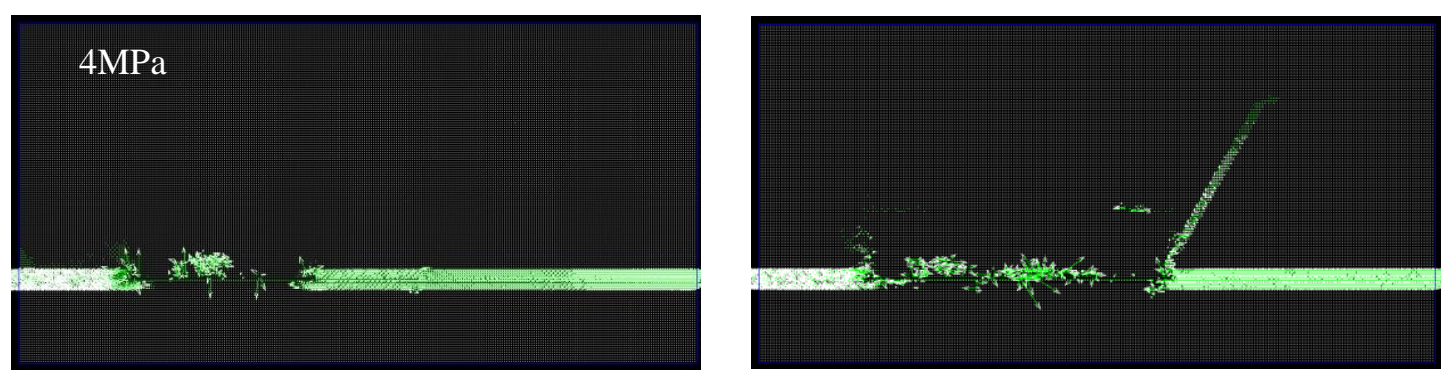

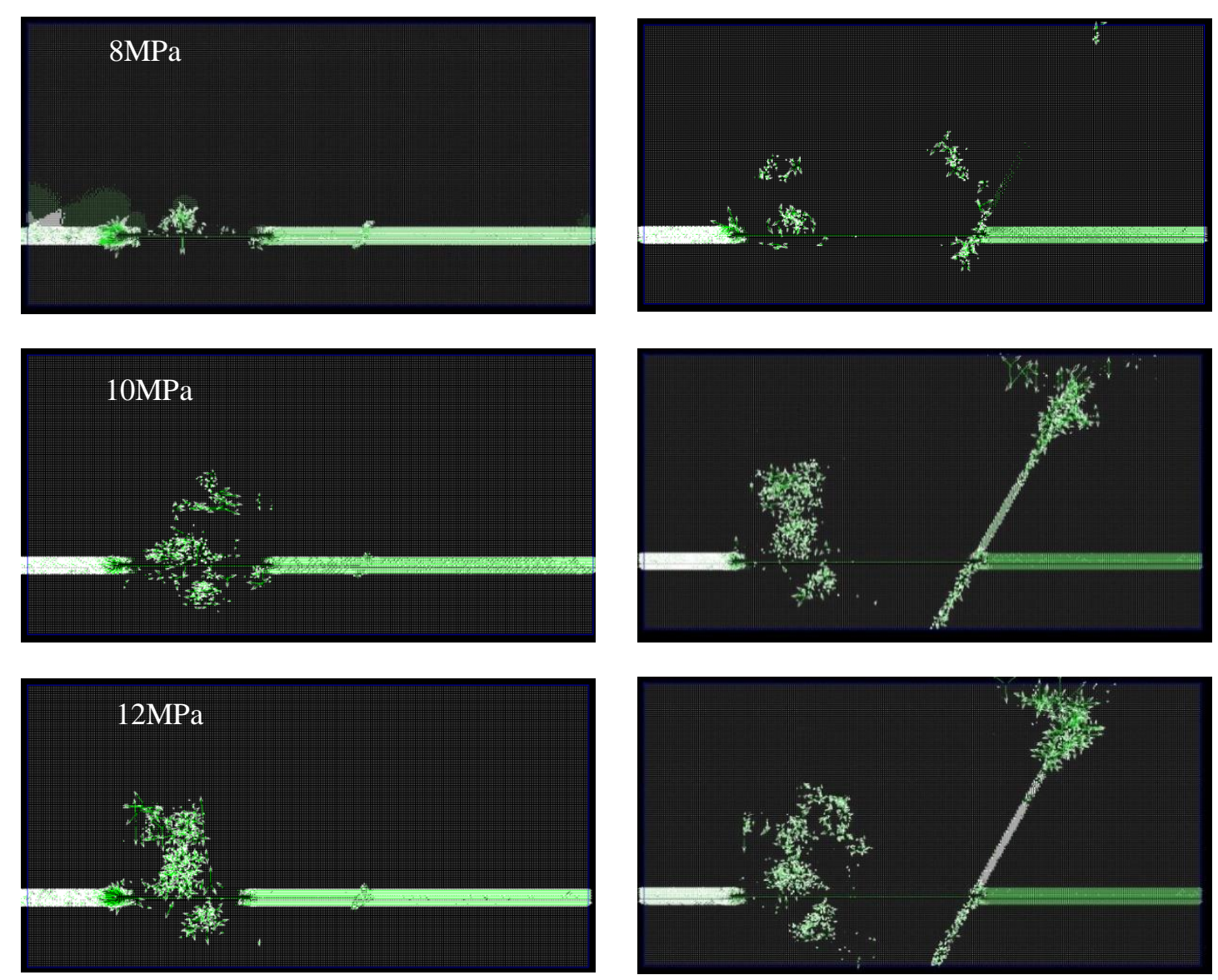

(a) grouting in rock mass

(b) grouting in fault

Fig. 6 Results of numerical analysis

The aforementioned simulation results demonstrated that the higher the grouting

pressure was, the higher the radius of slurry diffusion was, but the diffusion radius increase was not apparent when the grouting pressure reached to a certain pressure value. When the grouting pressure was10 12MPa, the diffusion distance of the slurry

31 changed slightly to approximately $50 \sim 55 \mathrm{~m}$. On one hand, the diffusion range of the

32 slurry was related to the grouting pressure. On the other hand, the diffusion range of

33 the slurry was related to the dominant direction of fracture. The slurry often diffused

34 along the dominant channel with good permeability and easy splitting of the weak

35 structural planes.

\section{$36 \quad 3.3$ Drilling structure design}

37 The ground directional borehole grouting was mainly through the near horizontal

38 drilling unit to enter the third limestone prior to mining, as well as to seal the cracks

39 with high pressure grouting. The borehole unit was arranged by the main drilling as 
40

41

well as the multiple first-level branches and secondary branch drilling, which had fan-shaped distribution. The distance in-between branch drillings was 50 110m. The drilling structure design is presented in Figure 7.

The drilling consisted of three segments. The first segment was the straight drilling (0 120m). The borehole diameter was $311 \mathrm{~mm}$. The size of casing was $244.5 \mathrm{~mm}$, putting the casing down to $20 \mathrm{~m}$ below the bedrock. Cementing was used to isolate the quaternary surface soil layer. The second segment was directional deflecting drilling. The borehole diameter was $216 \mathrm{~mm}$, and the size of casing was $177.8 \mathrm{~mm}$, putting the casing down to $30 \mathrm{~m}$ below the floor of 6th coal seam and close to the bedding. The third segment was directional bedding drilling of $152 \mathrm{mmin}$ diameter. During driling along the third limestone bedding, all branches sustained directional drilling in the third limestone bedding.

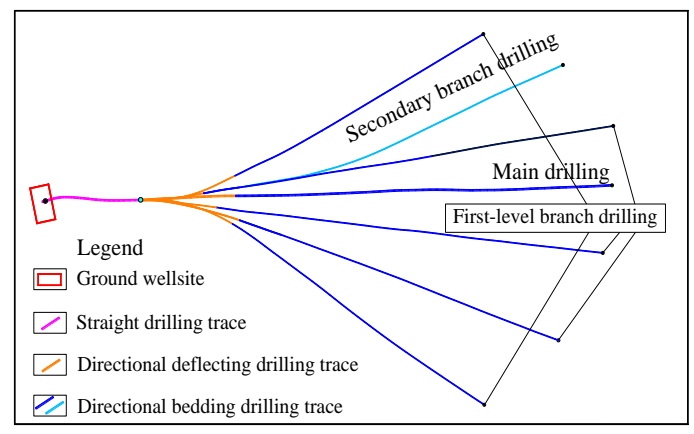

(a) Plane structure of drilling

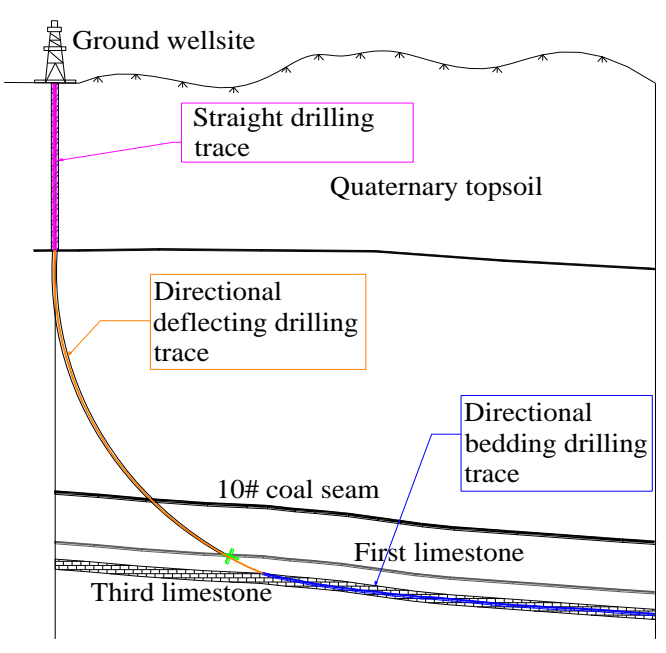

(b) Section structureof drilling

Fig. 7 Sketch of drilling structure design

\subsection{Layout of grouting drilling in study area}

Combined with the aforementioned analysis, it was determined that the orientation and spacing of branch drilling should be based on the following principles:

(1) The branch drilling should be intersected with the large angle of fault and folds axis as high as possible, also through the faults and folds.

(2) In order to ensure the complete filling and plugging of third limestone aquifers 
and fault fracture zones, the distance between the branch drilling should not exceed twice the diffusion radius. Simultaneously, the high efficiency and economic rationality should be taken into consideration. The drilling spacing should exceed the single drilling grouting diffusion range. Therefore, the distance between branch drillings should be between 50 110m.

(3) The scope of drilling grouting diffusion should cover the entire treatment area as far as possible.

According to the layout principle of the latter grouting drilling, the directional grouting drilling of II1027 and II1029 working faces in the study area was designed and is presented in Figure 8.

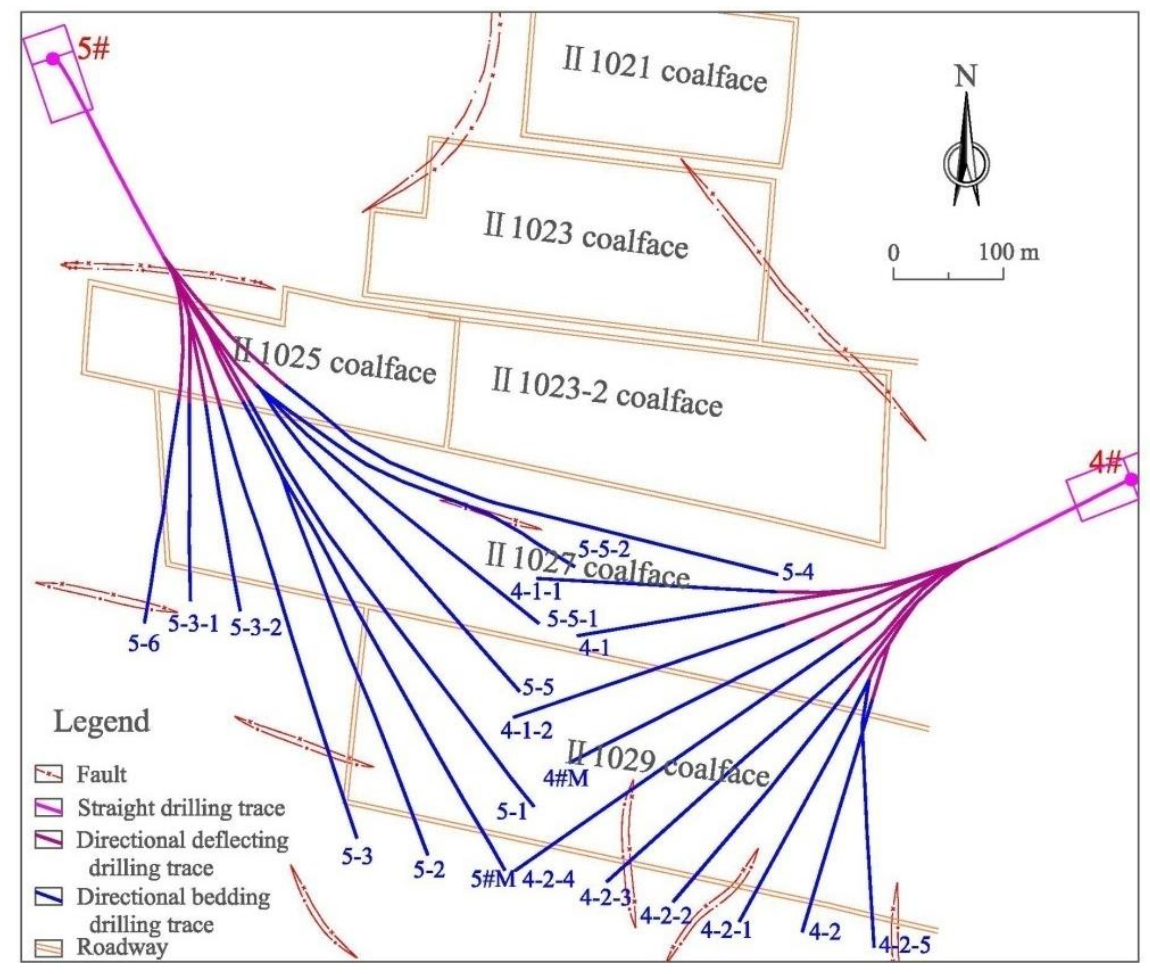

Fig. 8 Layout of grouting drilling in study area

\section{Grouting and verification of grouting effect}

\subsection{Grouting process}

The directional drilling grouting of this study was carried out through downward stage grouting and orifice-closed grouting methods ( $\mathrm{Li}$ and $\mathrm{Du} 2014$ ), which consisted of two stages: filling grouting and high pressure grouting.

(1) Filling grouting: When high-sized cracks or karst caves exist in the limestone, 
77 the high concentration cement slurry with a specific gravity of

78 approximately1.5 1.7t $/ \mathrm{m}^{3}$ is injected with the large displacement grouting pump of

$79260 \sim 600 \mathrm{~L} / \mathrm{min}$ to quickly fill the fissure or cave.

80 (2) High pressure grouting: In order to increase the diffusion distance and fill the

81 fine fissures, the high pressure grouting is used to spread the residual gap and

82 low-sized fissure in the rock mass to increase the reinforcement effect.

83 According to the "coal mine prevention and control water regulations" (State

84 Administration of Work Safety 2009), the grouting pressure should be twice the

85 maximum hydrostatic pressure $(4 \mathrm{MPa})$ of the injected aquifer, while the termination

86 pressure of the grouting drilling must not be lower than 2.5 times of the water

87 pressure. Due to the particularity of the grouting project, the construction could be

88 adjusted according to the actual situation in the field. The hydrostatic pressure of third

89 limestone was approximately 4MPa.Consequently, the final pressure of grouting

90 was 10 12MPa. Finally, the grouting absorption capacity was generally $40 \sim 60 \mathrm{~L} / \mathrm{min}$

91 and the stability time was $20 \sim 30 \mathrm{~min}$.

\section{$92 \quad 4.2$ Verification of grouting effect}

93 The water level plays a guiding role in drilling grouting. Through the analysis of

94 the water level and combined with the pressure water testing, the development degree

95 of the fracture, the connection between adjacent aquifers, the existence of abnormal

96 water pressure area, as well as the existence of faults and collapse columns could be

97 determined. Table 2 presents the water levels of each drilling in the II1027 and II1029

98 working faces. In this area, the third limestone water level elevation was usually

$99-180 \sim-230 \mathrm{~m}$. It could be observed that the water level of most drillings belonged to

100 the third limestone water level elevation, which demonstrated that the target location

101 of drilling was accurate and reliable, meeting the design requirements. 
Tbale 2 Statistics of water level for each drilling

\begin{tabular}{cccccccc}
\hline $\begin{array}{c}\text { The } \\
\text { drilling } \\
\text { unit }\end{array}$ & $\begin{array}{c}\text { Drilling } \\
\text { number }\end{array}$ & $\begin{array}{c}\text { Grouting } \\
\text { section }(\mathrm{m})\end{array}$ & $\begin{array}{c}\text { Groundwater } \\
\text { elevation }(\mathrm{m})\end{array}$ & $\begin{array}{c}\text { The } \\
\text { drilling } \\
\text { unit }\end{array}$ & $\begin{array}{c}\text { Drilling } \\
\text { number }\end{array}$ & $\begin{array}{c}\text { Grouting } \\
\text { section }(\mathrm{m})\end{array}$ & $\begin{array}{c}\text { Groundwater elevation } \\
(\mathrm{m})\end{array}$ \\
\hline & $4 \# \mathrm{M}$ & $785.22-1128$ & Not detected & & $5 \# \mathrm{M}$ & $800.62-980$ & Not detected \\
& $4-1 \#$ & $758.22-1191.92$ & -223.6 & & $5-1 \#$ & $865-1427$ & -215.4 \\
& $4-1-1 \#$ & $785-1222.2$ & -197.6 & & $5-2 \#$ & $909-1424$ & -193.4 (Instability) \\
& $4-1-2 \#$ & $861.5-1272$ & -256.6 & & $5-3 \#$ & $817-1368.63$ & -217.3 \\
& $4-2 \#$ & $785-1177$ & -263.6 & & $5-3-1 \#$ & $820-1140.78$ & -81.4 (Instability) \\
& $4-2-1 \#$ & $1177-1230$ & -153.6 & $5 \#$ & $5-3-2 \#$ & $849-1155.7$ & -4.1 (Instability) \\
& $4-2-2 \#$ & $909-1260$ & -173.9 & & $5-4 \#$ & $815-1331$ & -226 \\
& $4-2-3 \#$ & $870-1290$ & -193.4 & & $5-5 \#$ & $815-1328$ & -56.6 \\
& $4-2-4 \#$ & $840-1348.2$ & -111.1 (Instability) & & $5-5-1 \#$ & $892-1297$ & -193.9 \\
& $4-2-5 \#$ & $800-1242.34$ & -164.6 & & $5-5-2 \#$ & $800.62-1188$ & -203.4 \\
& & & & $5-6 \#$ & $807-1158.8$ & -216.4 \\
\hline
\end{tabular}

106

107 Following the completion of grouting, the audio frequency electric perspective

108 (AFEP) method (Zhang et al. 2013) was utilized to detect the grouting face (II1027

109 working face). The results demonstrated that the apparent conductivity was uniformly

110 distributed in most areas of the working face, while the apparent conductivity of the

$11140 \sim 70 \mathrm{~m}$ range below the floor was low. Also, only two relative anomalous regions

112 existed, reflecting the improved effect of the aquifer reconstruction of the floor

113 limestone.

114 Through the drilling of holes in the track trough, the relative anomalous regions of

115 AFEP, the structural fracture development and the abnormal grouting areas were

116 verified. The end position of each drilling was designed as the grouting target layer

117 (middle and lower part of third limestone). The layout of each drilling is presented in

118 Figure 9.

119 Each drilling was conducted with a $133 \mathrm{~mm}$ drill, while the casing was put down to

$1202 \sim 5 \mathrm{~m}$. Consequently, the drill size was changed to $94 \mathrm{~mm}$ and the casing was put

121 down to $25 \mathrm{~m}$. At the end, the $75 \mathrm{~mm}$ drill was driven to the bottom of the hole. Only

122 six drillings (D2\#, D3\#, D5\#, D8\#, D9\#, D12\#) sent water up in all test drillings,

123 while the amount of water only was $0.5 \sim 2.0 \mathrm{~m}^{3} / \mathrm{h}$. In addition, the D5\#, D9\# and D12\# 
124 drillings sent water up at the third limestone, while the water amounts were $0.5 \mathrm{~m}^{3} / \mathrm{h}$,

$1251.0 \mathrm{~m}^{3} / \mathrm{h}$ and $0.1 \mathrm{~m}^{3} / \mathrm{h}$, respectively. The D3\# drilling was first limestone with effluent

126 water, while the D\#2 andD\#8 were second limestone with effluent water. From the

127 aforementioned situation, it could be observed that the third limestone and above the

128 limestone aquifer grouting reconstruction effects were apparent. The first to third

129 limestone could be regarded as the equivalent aquiclude. The grouting sealing was

130 carried out subsequently to the drilling construction, which is referred to Table3.

131 In addition, through actual mining verification, no water inrush occurred during

132 mining, which indicated that the grouting reinforcement effect was apparent.

Table 3 List of drilling construction

\begin{tabular}{|c|c|c|c|c|c|c|c|c|}
\hline Drilling number & $\begin{array}{l}\text { Azimuthal } \\
\text { angles }\left(^{\circ}\right)\end{array}$ & $\begin{array}{l}\text { Pitch-down } \\
\text { angle }\left(^{\circ}\right)\end{array}$ & $\begin{array}{c}\text { Drilling } \\
\text { depth } \\
\text { (m) }\end{array}$ & $\begin{array}{l}\text { Water } \\
\text { inflow } \\
\left(\mathrm{m}^{3} / \mathrm{h}\right)\end{array}$ & $\begin{array}{c}\text { Position of water } \\
\text { inflow }\end{array}$ & $\begin{array}{l}\text { Final position of } \\
\text { drilling }\end{array}$ & $\begin{array}{l}\text { Grouting } \\
\text { flow }(\mathrm{t})\end{array}$ & $\begin{array}{c}\text { Grouting } \\
\text { pressure } \\
(\mathrm{MPa})\end{array}$ \\
\hline D1\# & 222 & 33.5 & 78 & l & l & Fourth limestone & 0.8 & 10 \\
\hline D2\# & 240 & 33.5 & 74.5 & 2 & Second limestone & Third limestone bottom & 2 & 10 \\
\hline D3\# & 290 & 41 & 65 & 0.5 & First limestone & Third limestone & 0.6 & 10 \\
\hline D4\# & 290 & 42 & 46 & l & l & Third limestone & 0.6 & 11 \\
\hline D5\# & 274 & 30 & 66 & 0.5 & Third limestone & Third limestone & 0.8 & 10 \\
\hline D6\# & 315 & 49 & 48 & I & I & Third limestone & 0.5 & 11 \\
\hline D7\# & 278.5 & 44 & 55 & I & I & Third limestone bottom & 0.35 & 10 \\
\hline D8\# & 80 & 52 & 74 & 1 & Second limestone & Third limestone & 1 & 10 \\
\hline D9\# & 261 & 25 & 73 & 1 & Third limestone & Third limestone & 1.4 & 9 \\
\hline D10\# & 283 & 66 & 50.6 & l & l & Third limestone bottom & 0.7 & 9 \\
\hline D11\# & 290 & 33.5 & 64.2 & I & & Third limestone & 1.2 & 10 \\
\hline D12\# & 305 & 15 & 90 & 0.1 & Third limestone & Third limestone bottom & 1.2 & 10 \\
\hline
\end{tabular}


135

136

\section{7}

138

139

140

141

142

143

144

145

146

147

148

149

150

151

152

153

154

155

156

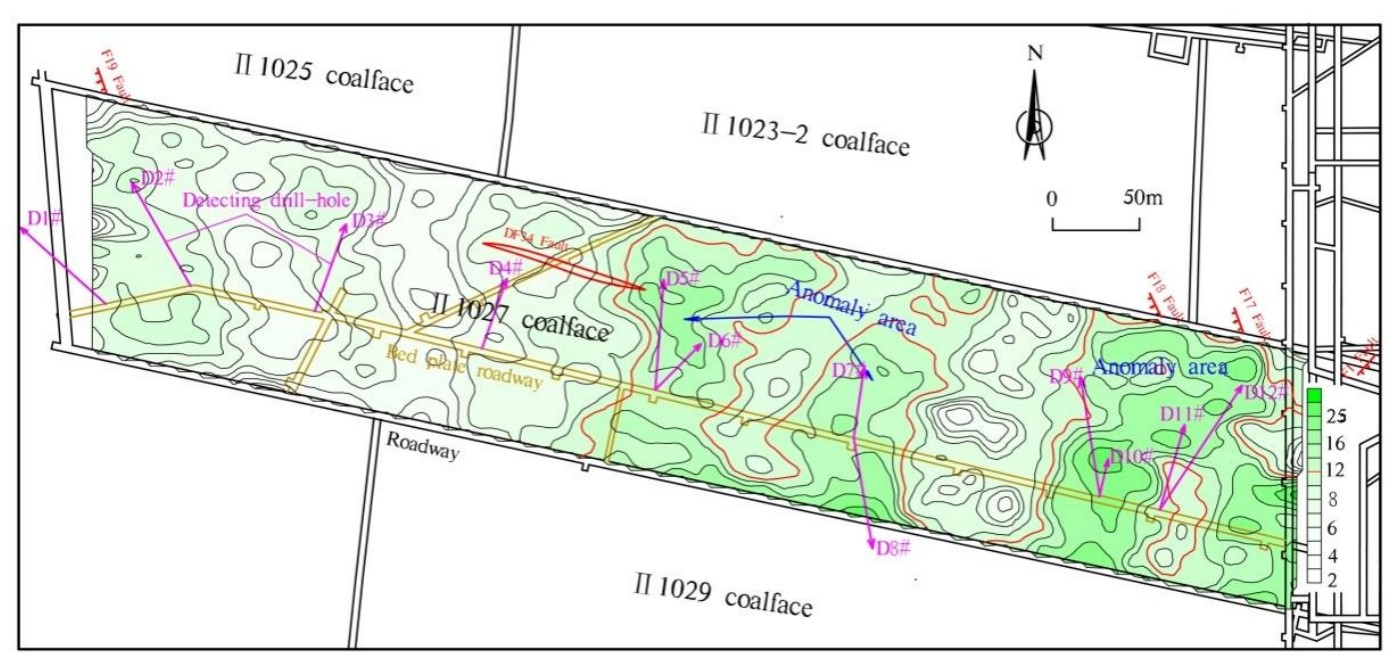

Fig. 9 Result of AFEP and layout of holedrilling in track trough.

\section{Conclusions}

The directional drilling technology and grouting technology were utilized to reconstruct the floor of the typical working face in the deep complex structure mining area of North China.The layout principle of the directional drilling was studied. The borehole unit was arranged through main drilling as well as multiple first-level branches and secondary branch drilling, which had fan-shaped distribution. The geological structure, the crustal stressand the slurry diffusion range were the main factors for the layout consideration of the drillings. The branch drillings were as much as possible through the faults and folds. The spacing of the branch drillings should exceed the single drilling grouting slurry diffusion range, whereas the scope of drilling grouting diffusion should significantly cover the entire treatment area. During grouting in the working faces of the study area, the water level of the grouting branch drilling demonstrated that the target layer of drilling was accurate and reliable, which conformed to the design requirements, indicating that the directional drilling technology was reliable. The AFEP method was utilized to detect the grouting working face. The results demonstrated that the apparent conductivity was uniformly distributed in most areas of the working face, while only two relative anomalous regions existed. Through holedrilling in the track trough, the relative anomalous regionsof AFEP, the structural fracture development and the abnormal grouting areas were verified. The results demonstrated that only certain drillings sent water up, 
157 which indicated that the grouting effects of third limestone and above the limestone

158 aquifer in the study area were apparent. Through actual mining, it was also verified

159 that the grouting reinforcement effect was good. Directional drilling grouting

160 technology had solved the problem of water disasters in the thin aquifer of deep

161 complex structure coal mines, through which, safe mining was realized.

162 Acknowledgments: The authors would like to express their gratitude to everyone who provided

163 assistance for the present study. The study is jointly Supported by "the Fundamental Research

164 Funds for the Central Universities"(grant number 2018QNA43).

165 Author Contributions: This work is the outcome of joint efforts of the two authors, who

166 contributed equally to conceive and design the research. They read and approved the final

167 manuscript.

168 Conflicts of Interest: The authors declare no conflicts of interest.

169 Reference

170 Cheng J, Sun X, Zheng G, Gao F, Kong X (2013) Numerical Simulations of Water-inrush induced

171 by Fault Activation during Deep Coal Mining based on Fluid-Solid Coupling Interaction.

172 Disaster advances, 6(11): 10-14

173 Dong C, Mu P, Li Q, Fang J, Zhao J, Hao Y, Zheng D (2014) Development Trend and Technology

174 of Coal Floor Grouting Reinforcement Drilling Construction. Coal Science and Technology,

$175 \quad 42(12): 27-31$

176 Ge J, Wang J (2007) Application of Stress Release by Lowing Water Pressure to Groundwater

177 Hazard Control in The Work Face in Liuqiao Coal Mine. Coal Engineering, (8): 63-65

178 Hao G, Li H, Du J (2014) Technology combined draining depressurization with floor grouting

179 reconstruction to liberate coal resource being on confined water. Shandong Coal Science and

180 Technology, (7): 154-155

181 Hu X, Wang L, Lu Y, Yu M (2014) Analysis of insidious fault activation and water inrush from the mining floor. International Journal of Mining Science and Technology, 24(4): 477-483

183 Li B, Chen Y (2016) Risk assessment of coal floor water inrush from underlying aquifers based on 
Li C, Du S (2014) Recovery Working Face Pre-mining Baseboard Grouting Reinforcement Technology Application. Coal and Chemical Industry, 37(11): 70-73

Lo KY, Kaniaru K (1990) Hydraulic fracture in earth and rock-fill dams. Canadian Geotechnical Journal, 27(4): 496-506

Meng Z, Yi W, Lan H, Wang M (2009) Water in rush characteristics of Fangezhuang coal mine field in Kailuan and its geological condition analysis of water inrush from coal seam floor. Chinese Journal of Rock Mechanics and Engineering, 28(2): 228-237

State Administration of Work Safety (2009) Rule of mine prevention and cure water disaster. Beijing: China Coal Industry Publishing House

Shi L, Gao W, Han J, Tan X (2017) A Nonlinear Risk Evaluation Method for Water Inrush Through the Seam Floor. Mine Water and the Environment, 36(4): 597-605

Sui W, Liu J, Yang S, Chen Z, Hu Y (2011) Hydrogeological analysis and salvage of a deep coalmine after a groundwater inrush. Environmental Earth Sciences, 62(4): 735-749

Sun W, Wu Q, Liu H, Jiao J (2015) Prediction and assessment of the disturbances of the coal

Sun W, Zhang S, Guo W, Liu W (2017) Physical Simulation of High-Pressure Water Inrush Through the Floor of a Deep Mine. Mine Water and the Environment, 36(4): 542-549

Tang CA, Yang WT, Fu YF, Xu XH (1998) A new approach to numerical method of modelling geological processes and rock engineering problems — continuum to discontinuum and linearity to nonlinearity. Engineering Geology, 49(3-4): 207-214

Tian C, Bai H, Qi J (2015) Grouting Reconstruction of Tectonic Floor Mined on High Pressurebearing Water. Safety in Coal Mines, 46(7): 169-171

Wang X, Pan G, Zhai J (2012) Analysis on Suitability of Water Prevention and Control Measures

211 Xu Y, Li J, Liu B (2014) Reinforcement of working face by grouting in floor in Jiaozuo coal 
212 mining area. Coal Geology \& Exploration, 42(4): 50-54

213 Yang T, Shi W, Liu H, Yang B, Yang X, Liu Z (2017) A non-linear flow model based on flow

214 translation and its application in the mechanism analysis of water inrush through collapse

215 pillar. Journal of China Coal Society, 2017, 42(2): 315-321

216 Zhang J, Wang Y, Qin H, Liu G, Zhao P (2013) The Application of Audio Frequency Electric

217 Perspective to Detection of Coal Mine Work Face. Chinese Journal of Engineering

$218 \quad$ Geophysics, 140(4): 551-554

219 Zhou SM, Chen JJ (2002) Hydrofracture grouting in soft flowing mucky ground for a metro tunnel.

220 Chinese Journal of Geotechnical Engineering, 24(2): 222-224 